\title{
The Skin and Plasma Antioxidant Enzyme Activities in Patients With Vitiligo
}

\author{
Vitiligolu Hastalarda Deri ve Plasma Antioksidan Enzim Aktiviteleri
}

\author{
Kadir BATÇIOĞLU ${ }^{1}$, Ersoy HAZNECİ², Çetin ÖZTÜRK ${ }^{3}$, Aysun Bay KARABULUT ${ }^{3}$, Neşe KARADAĞ ${ }^{4}$ \\ ${ }^{1}$ Inonu University, Faculty of Pharmacy, Department of Biochemistry, Malatya \\ ${ }^{2}$ Acibadem Hospital, Dermatology Department, Bursa \\ ${ }^{3}$ Inonu University, Faculty of Medicine, Department of Biochemistry, ${ }^{4}$ Pathology, Malatya
}

Submitted / Başvuru tarihi: 06.01.2009 Accepted / Kabul tarihi: 13.02.2009

\begin{abstract}
Objective: It is known that oxidative stress could be an important factor in the pathogenesis of vitiligo disease. We aimed to investigate the possible relationship between vitiligo pathogenesis and the change of antioxidant capacity of skin and plasma in patients with vitiligo.

Material and Methods: In this study we have examined normal and vitiliginous skin and plasma GPx, SOD and CAT activities by spectrophotometric methods in 40 vitiligo patients and 15 controls.
\end{abstract}

Results: Results of tissue enzyme activities (as $\mathrm{U} / \mathrm{mg}$ prt and Mean \pm SD); were $0.64 \pm 0.09 ; 0.89 \pm 0.15 ; 0.41 \pm 0.57$ for SOD enzyme, $170.98 \pm 12.35 ; 182.13 \pm 13.48$; $121.91+16.03$ for GPx enzyme and $78.92 \pm 10.34$; $94.99 \pm 10+47 ; 55.95 \pm 7.24$ for CAT enzyme in involved skin, uninvolved skin and control groups respectively. Plasma levels of these enzymes were $37.19 \pm 1.53$; $39.53 \pm 3.32$ SOD enzyme, $381.57 \pm 12.67 ; 346.13 \pm 21.90$ for GPx and $66.72 \pm 8.86 ; 61.24 \pm 6.32$ for CAT enzyme in vitiligo and control groups respectively.

Conclusion: There is no correlation between skin and plasma antioxidant enzyme activities in vitiligo patients, or in healthy controls. High glutathione peroxidase and catalase activities in vitiligous skin $(p<0.05)$ especially might be a result of anti oxidative stress response against oxidative stress via peroxides.

Key words: Vitiligo; free radicals; antioxidants; skin pigmentation; oxidative damage.
Amaç: Oksidatif stresin vitiligo patogenezinde önemli bir faktör olduğu bilinmektedir. Biz bu çalışmada, vitiligolu hastalarda deri ve plasma antioksidan kapasite değişikliği ile vitiligo patogenezi arasındaki olası ilişkiyi araştırmayı amaçladık.

Gereç ve Yöntemler: Bu çalışmada 40 vitiligolu hasta ile 15 sağlıklı kontrollere ait normal ve vitiligolu deri ve plasma örneklerinde katalaz, glutatyon peroksidaz ve süperoksit dismutaz enzim aktiviteleri spektrofotometrik metodlarla ölçüldü.

Bulgular: Doku enzim aktivitesi (U/mg prt ve OrttSD olarak) sonuçlarımız; SOD enzimi için sırasıyla tutulum olan deride, tutulum olmayan deride ve kontrol gurubunda $0.64 \pm 0.09 ; 0.89 \pm 0.15 ; 0.41 \pm 0.57$ 'dir, GPx enzimi için $170.98 \pm 12.35 ; 182.13 \pm 13.48 ; 121.91 \pm 16.03$ 'dür, CAT enzimi için $78.92 \pm 10.34 ; 94.99 \pm 10 \pm 47 ; 55.95 \pm 7.24$ 'dür. Plazma düzeyleri sırasıyla vitiligo ve control gurubunda SOD enzimi için $37.19 \pm 1.53$; $39.53 \pm 3.32$, GPx enzimi için $381.57 \pm 12.67 ; 346.13 \pm 21.90$ ve CAT enzimi için $66.72 \pm 8.86 ; 61.24 \pm 6.32$ 'dir.

Sonuç: Vitiligolu hastalarda ve sağlıklı kontrol gurubunda deri ve plasma antioksidan enzim aktiviteleri arasında net bir korelasyon bulunmamaktadır. Özellikle vitiligolu alanda yüksek katalaz ve glutatyon peroksidaz aktivitesi $(p<0.05)$ bu bölgede peroksitler aracılığıyla oluşan oksidatif strese karşı geliştirilen antioksidan yanıtın bir sonucu olabilir.

Anahtar sözcükler: Vitiligo; serbest radikaller; antioksidanlar; deri pigmentasyonu; oksidatif hasar.

Correspondence (iletişim adresi): Dr. Kadir Batçıŏlu. Inonu University, Faculty of Pharmacy, Biochemistry Department, Malatya, Turkey. Tel: 04223410600 e-mail (e-posta): kadirbatci@inonu.edu.tr

() Trakya Üniversitesi Tıp Fakültesi Dergisi. AVES Yayıncılık tarafından basılmışır. Her hakkı sakıdır.

(๑) Medical Journal of Trakya University. Published by AVES Publishing. All rights reserved. 


\section{INTRODUCTION}

The etiology and pathogenic mechanism of vitiligo is still unclear. Recently, the involvement of oxidative stress in the pathophysiology of vitiligo has been shown. ${ }^{[1,2]}$ Increased oxidative stress, accumulation of free radicals and reactive oxygen species (ROS) and associated changes in epidermal component of vitiliginous skin have been reported many times. ${ }^{[3-5]}$ However, ROS are generated as by-products of normal cellular metabolism; an unbalanced production of ROS occurs frequently in cells, particularly following exposure to various chemicals, radiation, hyperoxia, and ischemiareperfusion or during tissue inflammation. Moreover, it has recently been revealed that ROS modulate the physiological state of cells and influence cell death. ${ }^{[6]}$ A relationship between ROS and apoptosis has been suggested by many studies. Some histological and laboratory data indicate that apoptosis plays an important role during degeneration of melanocytes in vitiligo patients. ${ }^{[7,8]}$

Mammalian cells are equipped with both enzymatic and nonenzymatic antioxidant activities to minimize the cellular oxidative damage. The enzymatic antioxidant mechanisms include superoxide dismutases (SOD), catalase (CAT) and glutathione peroxidase (GPx), and these antioxidants can prevent oxidative damage in several cell types. In vitiligo, both an imbalance of the intracellular redox status and a significant depletion of enzymatic and non-enzymatic antioxidants feature of vitiligo patients, and an abnormal oxidative stress might be the causes of melanocyte degeneration. ${ }^{[2]}$

We aimed to investigate the antioxidant enzyme activity levels of plasma and skin in vitiligo patients and in healthy controls. We used normal full thickness skin samples for this study. So far, there is no study about antioxidant enzymes on full thickness skin biopsy in patients with vitiligo.

\section{MATERIALS AND METHODS}

Forty (23 female, 17 male) inactive vitiligo patients and fifteen (11 female, 4 male) healthy controls were included in this study. Patient ages ranged from 9 to 56 years $(27 \pm 13)$. The control group consisted of healthy volunteers, whose ages ranged from $16-52$ years $(35 \pm 13)$. The Ethic Committee approved the protocol for this study; all subjects gave his/her protector informed consent. The following laboratory tests were performed; erythrocyte sedimentation rate, blood cell counts and indexes; glucose, electrolytes, kidney and liver function tests. The patients with normal biochemical analysis results were included the study. The patients had not been under any therapeutic regimen for the previous 2 months and had not received drugs containing iron and/or vitamins. All individuals with any history of smoking and alcohol habits were excluded from the study.

Preparation of the samples: Skin and blood samples were taken at the same time. Skin samples of controls and vitiligo patients, from non-lesional and lesional skin, were taken by $4 \mathrm{~mm}$ punch biopsy (two times) under local anesthesia with prilocain (Citanest ${ }^{\circledR} \% 2$ ), and immediately after the biopsy, subcutaneous lipid tissue were separated gently. Tissues were frozen in liquid nitrogen, and stored in a deep freeze $(-40 \mathrm{C})$ for at most 2 weeks until they were used. Just before measurement, all the frozen tissues were transferred into 14 $\mathrm{ml}$ tubes. PBS $(1 \mathrm{ml})$ placed in a round bottom tube and homogenized using a homogenizer (Ultra Turpax T2S Basic-Labortechnik) at 20 000-cycle speed until tissue was fully ground (about 30-60 seconds). Then samples were centrifuged at $15000 \mathrm{~g}$. for 15 minutes.

Ten ml blood was drawn from the median cubital vein of the patient and control groups into heparin washed tubes. The blood samples were centrifuged at 1000x $g$ for 10 minutes at $+4^{\circ} \mathrm{C}$, and the upper plasma phase was withdrawn by pipette and transferred into polypropylene tubes, and stored at $-40^{\circ} \mathrm{C}$.

Determination of Protein Levels: Protein determinations in plasma and tissue homogenates were made according to Lowry et al. using BSA as standard. ${ }^{[9]}$

Measurement of CAT Activity: CAT activity was measured by the Aebi ${ }^{[10]}$ method as described in the literature. The principle of this method was based on decomposition of $\mathrm{H}_{2} \mathrm{O}_{2}$ and decreasing absorbance at 240 nm. Conversion of $\mathrm{H}_{2} \mathrm{O}_{2}$ into to $\mathrm{H}_{2} \mathrm{O}$ and $\mathrm{O}_{2}$ in one minute under standard conditions was accepted as enzyme reaction velocity.

Measurement of SOD Activity: SOD (E.C.1.15.1.1) enzyme activity determination was based on the production of $\mathrm{O}_{2}^{-}$, from xanthine by xanthine oxidase and reduction of nitroblue tetrazolium (NBT) by the produced $\mathrm{O}_{2}-$ SOD enzyme also dismutated two superoxide and produced $\mathrm{H}_{2} \mathrm{O}_{2} \cdot{ }^{[11]}$

Measurement of GPx Activity: GPx activity measurements were conducted according to Lawrence and Burk $^{[12]}$. The change in absorbance at $340 \mathrm{~nm}$ was monitored for $1 \mathrm{~min}$. A blank with all ingredients except supernatant was also monitored. Specific activity was calculated as $\mathrm{U} / \mathrm{mg}$ protein for plasma and supernatant samples.

Statistical analyses were carried out on the SPSS 10 computer program, utilizing "Mann-Whitney U test", "Wilcoxon Signed Rank Test" and "partial correlation coefficients" tests.

\section{RESULTS}

All results were shown in Tables 1 and 2 .

Plasma antioxidant enzyme activities were found statistically insignificant in the vitiligo patients compared to the control group $(p>0.05)$. However, the results showed that GPx activities were increased significantly in vitiligo patients' uninvolved (mean \pm SD:182.13 \pm 13.48 
Table 1. Skin enzyme activities in vitiligo patients and control group. All results in tables are given as "Mean $\pm S D^{\prime \prime}$

\begin{tabular}{lccc}
\hline Skin & $\begin{array}{c}\text { SOD }(\mathrm{U} / \mathrm{mg} \\
\text { protein) }\end{array}$ & $\begin{array}{c}\text { CAT }(\mathrm{U} / \mathrm{mg} \\
\text { protein })\end{array}$ & $\begin{array}{c}\text { GPx }(\mathrm{U} / \mathrm{mg} \\
\text { protein })\end{array}$ \\
\hline Involved skin $(\mathrm{n}=33)$ & $0.64 \pm 0.09$ & $78.92 \pm 10.34$ & $170.98 \pm 12.35^{\mathrm{a}}$ \\
Uninvolved skin $(\mathrm{n}=34)$ & $0.89 \pm 0.15$ & $94.99 \pm 10.47^{\mathrm{a}}$ & $182.13 \pm 13.48^{\mathrm{a}}$ \\
Control $(\mathrm{n}=15)$ & $0.41 \pm 0.57$ & $55.95 \pm 7.24$ & $121.91 \pm 16.03$ \\
\hline
\end{tabular}

a: $p<0.05$ compared with control.

Table 2. Plasma enzyme activities in vitiligo patients and control group. All results in tables are given as "Mean $\pm S D^{\prime \prime}$

\begin{tabular}{|c|c|c|c|}
\hline Plasma & $\begin{array}{c}\mathrm{SOD}(\mathrm{U} / \mathrm{mg} \\
\text { protein })\end{array}$ & $\begin{array}{c}\text { CAT (U/mg } \\
\text { protein) }\end{array}$ & $\begin{array}{c}\text { GPx }(\mathrm{U} / \mathrm{mg} \\
\text { protein) }\end{array}$ \\
\hline Vitiligo patients $(n=37)$ & $37.19 \pm 1.53$ & $66.72 \pm 8.86$ & $381.57 \pm 12.67$ \\
\hline Control $(n=15)$ & $39.53 \pm 3.32$ & $61.24 \pm 6.32$ & $346.13 \pm 21.90$ \\
\hline
\end{tabular}

$\mathrm{U} / \mathrm{mg}$ protein $)(\mathrm{p}=0.004)$ and vitiliginous skin (mean \pm SD: $170.98 \pm 12.35 \mathrm{U} / \mathrm{mg}$ protein) $(\mathrm{p}=0.005) \mathrm{com}-$ pared with control subjects. The CAT activities were found to be high $($ mean \pm SD: $94.99 \pm 10.47 \mathrm{U} / \mathrm{mg}$ protein) in the uninvolved skin of vitiligo patients, but not in vitiliginous skin (mean \pm SD: $78.92 \pm 10.34 \mathrm{U} / \mathrm{mg}$ protein) when compared with control group skin $(\mathrm{p}=0.014)$. There was no significant difference in SOD activities in both skin examples, ie vitiliginous (mean \pm SD:0.64 \pm 0.09 $\mathrm{U} / \mathrm{mg}$ protein $), \quad(\mathrm{p}>0.05)$ and uninvolved sites (mean \pm SD:0.89 $\pm 0.15 \mathrm{U} / \mathrm{mg}$ protein), $(\mathrm{p}>0.05)$. Although skin and plasma SOD and CAT levels were not correlated, there was a significant correlation between skin and plasma GPx levels ( $\mathrm{p}=0.036)$.

\section{DISCUSSION}

Our results clearly show that the serum composition of antioxidant enzymes in patients with vitiligo are not significantly different from those of healthy controls. The skin is the largest tissue of the human body, with an approximate size of $1.8 \mathrm{~m}^{2}$, where numerous fine-tuned mechanisms act in a concerted manner to maintain homeostasis. Recently, it has been shown in vivo and in vitro that patients with the pigmentation disorder vitiligo accumulate $\mathrm{mM}$ levels of hydrogen peroxide $\left(\mathrm{H}_{2} \mathrm{O}_{2}\right)$ and high concentration of ROS in their epider$\mathrm{mis}^{[13]}$. It is well established that up to millimolar levels of $\mathrm{H}_{2} \mathrm{O}_{2}$ lead to the upregulation of antioxidant enzymes such as SOD, CAT and GPx. ${ }^{[1,15]}$ Possible sources of endogenous $\mathrm{H}_{2} \mathrm{O}_{2}$ production increased the activities of epidermal monoamine oxidase A, NADPH-oxidases, SOD, inducible nitric oxide synthase, increased levels of TNF $\alpha$ and photo-oxidation of epidermal 6-biopterin and sepiapterin. ${ }^{[16]}$ Increased $\mathrm{H}_{2} \mathrm{O}_{2}$ concentration may cause the increased antioxidant capacity to compensate the oxidative damage of subcellular components such as lipids, proteins and DNA.
On the other hand, Schallreuter et al. ${ }^{[17,18]}$ reported that a defective recycling of tetrahydrobiopterin in the phenylalanine hydroxylase reaction in the epidermis has been also proposed as a possible pathogenetic factor of vitiligo. This metabolic impairment might lead to an accumulation of $\mathrm{H}_{2} \mathrm{O}_{2}$ within the epidermis and to the consequent oxidation of (6R)-5,6,7,8-tetrahydrobiopterin, the essential cofactor of phenylalanine hydroxylation reaction, to 6-biopterin, which is toxic to human melanocytes. ${ }^{[19]}$ Davis et al. ${ }^{[20,21]}$ established previously that the inhibition of phenylalanine hydroxylase causes the release of $\mathrm{H}_{2} \mathrm{O}_{2}$ due to the instability of the 4a-peroxytetrahydrobiopterin intermediate in the catalytic cycle. It is possible that the inhibition of phenyl alanine hydroxylase via $\mathrm{H}_{2} \mathrm{O}_{2}$ yields a decreased L-tyrosine pool with an altered melanin biosynthesis in vitiligo melanocytes.

The generation of $\mathrm{H}_{2} \mathrm{O}_{2}$ as a by-product could be responsible for the alteration of CAT and GPx enzyme activities in the skin and melanocyte damage. Jones et al. ${ }^{[22]}$ reported that GPx has a higher affinity for $\mathrm{H}_{2} \mathrm{O}_{2}$ than CAT, suggesting that the peroxides are metabolized mainly by GPx in the organism. In general, the most striking changes between the enzymes are seen in GPx. The probable reason for this is that the first defence against the peroxides comes from the GPx and increasing oxidative stress and CAT are involved in this defence. Therefore, probably GPx enzyme activity may be more sensitive to high $\mathrm{H}_{2} \mathrm{O}_{2}$ concentration, as according to our skin results. It seems possible that CAT and GPx activities in uninvolved skin might be increased by upregulation mechanisms, as an adaptation against to oxidative stress. Agrawal et al. ${ }^{[5]}$ reported increased MDA levels and SOD activity in all different age groups of vitiligo patients and decreased whole blood reduced glutathione levels and erythrocyte GPx and glucose-6-phosphate dehydrogenase activity. Arican et al. ${ }^{[23]}$ reported increased MDA levels and SOD activity also. However, Passi et al. ${ }^{[16]}$ measured SOD levels in the epidermis of patients with active vitiligo and reported that there was no significant change compared with control. In addition, Picardo et al. ${ }^{[24]}$ reported that in-patients with active vitiligo, the levels of blood $\mathrm{Cu}$ / $\mathrm{Zn}$ SOD activities were not different from controls. Similarly, in our previous study, we reported increased erythrocyte SOD activity and unchanged plasma GPx and SOD activity levels in vitiligo patients compared with healthy controls. ${ }^{[25]}$ Also, Yildırım et al. ${ }^{[26]}$ reported significantly higher level of erythrocyte and plasma SOD activity among patients with generalized stable vitiligo. We could not find any change of the enzyme activities in plasma. Oxidative stress and antioxidant enzyme activities are active and repeatedly change. We believe that these different results depend on activity and/or the stage of the vitiligo disease, or might depend on seasonal and/or daytime fluctuations of skin and plasma antioxidant status at the time of biopsy and blood sampling. 
On the other hand, the variations of antioxidant enzyme activities in oxidative stress are linked with genetic control mechanisms. It is possible that, in the case of low concentrations of ROS, mRNA expression of some antioxidant enzymes may be stimulated. ${ }^{[27,28]}$ However, it has not yet been determined extensively which molecules actively participate in this mechanism. Specific molecular studies on the subject are still needed.

In conclusion, we believe that the support of the skin antioxidant system via nonenzymatic antioxidant compounds and antioxidant enzymes may be useful in preventing melanocyte degeneration which occurs due to oxidative damage in vitiligo.

\section{Acknowledgement}

This research was generously supported by grants from the Turkish Dermatology Society.

\section{Conflict of Interest}

No conflict of interest declared by the authors.

\section{REFERENCES}

1. Schallreuter KU, Wood JM, Berger J. Low catalase levels in the epidermis of patients with vitiligo. J Invest Dermatol. 1991;97:1081-5.

2. Maresca V, Roccella M, Roccella F, Camera E, Del Porto G, Passi $S$, et al. Increased sensitivity to peroxidative agents as a possible pathogenic factor of melanocyte damage in vitiligo. J Invest Dermatol 1997;109:310-3.

3. Moellmann G, Klein AS, Scollay DA, Nordlund JJ, Lerner AB. Extracellular granular material and degeneration of keratinocytes in the normally pigmented epidermis of patients with vitiligo. J Invest Dermatol 1982;79:321-30.

4. Bhawan J, Bhutani LK. Keratinocyte damage in vitiligo. J Cutan Pathol 1983;10:207-12.

5. Agrawal D, Shajili EM, Marfatia YS, Begum R. Study on the Antioxidant Status of Vitiligo Patients of Different Age Groups in Baroda Pigment Cell Res. 2004;17:289-94.

6. Kroemer G, Dallaporta B, Resche-Rigon M. The mitochondrial death/life regulator in apoptosis and necrosis. Annu Rev Physiol 1998;60:619-42.

7. Tastan HB, Akar A, Orkunoglu EF, Arca E, Inal A. Association of HLA Class I antigens and HLA Class II Alleles with Vitiligo in a Turkish Population. Pigment Cell Res. 2004;17:181-7.

8. Lorini R, Orecchia G, Martinetti M, Dugoujon JM, Cuccia M. Autoimmunity in vitiligo: relationship with HLA, Gm and Km polymorphisms. Autoimmunity 1992;11:255-60.

9. Lowry OH, Rosebrough NJ, Farr AL, Randall RI Protein measurement with the folin phenol reagent. J Biol Chem 1951;193:265-75

10. Aebi H. Catalase in vitro. In: Packer L, editor. Methods in Enzymol. New York: Academic Press; 1984;121-6.

11. Podczasy JJ, Wei R. Reduction of iodonitrotetrazolium violet by superoxide radicals. Biochem Biophys Res Commun 1988;150:1294-301.
12. Lawrence RA, Burk RF. GPX activity in rat liver. Biochem Biophys Res Commun 1976;71:952-8.

13. Folch J, Lees M, Sladane-Stanley GHA. Simple method for the isolation and purification of total lipids from animal tissues. J Biol Chem. 1957;226:497-509.

14. Christie WW, (editor). Gas Chromatography and Lipids. Glasgow: The Oily Press; 1990.

15. Frings CS, Frendley TW, Dunn RT, Queen CR. Improved determination of total serum lipids $\mathrm{b}$ the sulfo-phosphovanilin reaction. Clin Chem. 1972;18:673-4.

16. Dell'Anna ML, Ottaviani M, Albanesi V, Vidolin AP, Leone G, Ferraro C, et al. Membrane lipid alterations as a possible basis for melanocyte degeneration in vitiligo. J Invest Dermatol. 2007;127:1226-33.

17. Schallreuter KU, Wood JM, Ziegler I, Lemke KR, Pittelkow MR, Lindsey NJ, et al. Defective tetrahydrobiopterin and catecholamine biosynthesis in the depigmentation disorder vitiligo. Biochimica et Biophysica Acta. 1994;1226:181-92.

18. Rokos H, Beazley WD, Schallreuter KU. Oxidative stress in vitiligo:photo-oxidation of pterins produces $\mathrm{H} 2 \mathrm{O} 2$ and pterin-6-carboxylic acid Biochem Biophys Res Comm. 2002;12:805-11.

19. Passi S, Randinetti M, Maggio F, Stancato A. Epidermal Oxidative Stress In Vitiligo. Pigment Cell Res. 1998;11:81-5.

20. Davis MD, Kaufman S. Evidence for the formation of the 4a-carbinolamine during the tyrosine dependent oxidation of tetrahydrobiopterin by rat liver phenylalanine hydroxylase. J Biol Chem. 1989;264:8585-96.

21. Davis MD, Ribeiro P, Tipper J, Kaufman. S 7-tetrahydrobiopterin, a naturally occurring analogue of tetrahydrobiopterin is a cofactor for and a potential inhibitor of the aromatic amino acid hydroxylases. Proc Natl Acad Sci. 1992;89:10109-13.

22. Jones DP, Eklow L, Thor H. Metabolism of hydrogen peroxide in isolated hepatocytes: relative contribution of catalase and glutathione peroxidase in decomposition of endogenously generated $\mathrm{H} 2 \mathrm{O} 2$. Arch Biochem Biophys. 1981;210:515-6.

23. Arican O, Kurutas EB. Oxidative stress in the blood of patients with active localized vitiligo. Acta Dermatovenerol Alp Panonica Adriat. 2008;17:12-6.

24. Picardo M, Passi S, Morrone A, Grandinetti M, Di Carlo A, Ippolito F. Antioxidant status in the blood of patients with active vitiligo. Pigment Cell Res. 1994;7:110-5.

25. Hazneci E, Karabulut AB, Ozturk C, Batcioglu K, Dogan G, Karaca S. A comparative study of superoxide dismutase, catalase and glutathione peroxidase activities and nitrate levels in vitiligo patients. Int J Dermatology. 2005;44:636-40.

26. Yıldırım M, Baysal V, Inaloz HS, Kesici D, Delibas N. The role of oxidants and antioxidants in generalized vitiligo. J Dermatol. 2003;30:104-8.

27. Dalton TP, Shertzer HG, Puga A. Regulation of gene expression by reactive oxygen. Annu Rev Toxicol. 1999;39:67-101

28. Janssen YM, Van Houten B, Borm PJ, Mossman MT. Cell and tissue responses to oxidative stres. Lab Invest. 1993;69:261-74. 